\title{
Wybrane problemy transformacji struktur przemyslowych w Federacji Rosyjskiej
}

W Rosji realizowane są współcześnie bardzo trudne reformy polityczne i gospodarcze. Szczególnie złożone problemy dawnych struktur ujawniły się w przemyśle. Istnieje jednakże obecnie silna wola polityczna, przejawiana głównie przez prezydenta i rząd, aby kontynuować zmiany struktur przemysłowych w Rosji, dokonujące się w procesie przechodzenia do gospodarki rynkowej. Oczekiwany wzrost wartości i wielkości produkcji będzie możliwy do osiągnięcia jedynie wówczas, gdy wdrożone zostaną głębokie reformy w całym sektorze przemysłowym.

Rosja zajmuje jedno z czołowych miejsc w świecie pod względem zasobów bogactw mineralnych, a w szczególności energetycznych; np. w zasobach gazu ziemnego 1. miejsce w świecie (30\% zasobów światowych), ropy naftowej 6 . miejsce w świecie (13\% zasobów światowych). Większość zasobów energetycznych oraz rud metali znajduje się na Syberii i na Dalekim Wschodzie. W ostatnich latach - już po rozpadzie ZSRR - zostały odkryte nowe złoża, zarówno na lądzie jak i na szelfie przybrzeżnych mórz północnych. Zasobne i zróżnicowane złoża surowców mineralnych, pozwalają na wszechstronny rozwój przemysłu przetwórczego. Jednakże mimo znacznych rozmiarów produkcji przemysłowej, Rosja ustępuje Stanom Zjednoczonym Ameryki, Japonii, Niemcom, Wielkiej Brytanii, Francji oraz większości innych wysoko rozwiniętych krajów o mniejszych globalnych rozmiarach produkcji, ale dużych w przeliczeniu na jednego mieszkańca, ustępuje także w zakresie poziomu nowoczesności przemysłu. Dotyczy to przede wszystkim struktury produkcji, stosowanych technologii wytwarzania, jakości produkowanych dóbr oraz wartości produkcji na jednego mieszkańca. W Federacji Rosyjskiej bowiem - czynnikiem wpływającym na strukturę produkcji przemysłowej jest nadal wielkość kraju i jego bogata baza surowcowa.

Rosja jest krajem cechującym się dużym zużyciem energii na jednostkę produktu krajowego brutto. Jest to odzwierciedleniem wysokiej energochłonności rosyjskiej gospodarki, w tym przemysłu, który jest głównym użytkownikiem energii. 
Tabela 1. Struktura gałęziowa przemysłu wg wartości produkcji w $1999 \mathrm{r}$.

\begin{tabular}{|l|c|}
\hline \multicolumn{1}{|c|}{ Przemysły } & $\begin{array}{c}\text { Udział w wartości produkcji } \\
\text { przemyslowej ogółem (w\%) }\end{array}$ \\
\hline Elektroenergetyka & 12,9 \\
\hline Przemysł paliw & 17,8 \\
\hline Hutnictwo żelaza & 9,3 \\
\hline Hutnictwo metali nieżelaznych & 7,0 \\
\hline Przemysł chemiczny i petrochemiczny & 7,3 \\
\hline Przemysł maszynowy i metalowy & 18,2 \\
\hline Przemysł drzewny i celulozowo-papierniczy & 4,7 \\
\hline Przemysł materiałów budowlanych & 4,0 \\
\hline $\begin{array}{l}\text { Przemysł lekki (włókienniczy, odzieżowy, skórzany, } \\
\text { obuwniczy, futrzarski) }\end{array}$ & 1,8 \\
\hline Przemysł spożywczy & 12,4 \\
\hline Ogółem przemysł & 100,0 \\
\hline
\end{tabular}

Źródło: Socjalno-ekonomiczieskoje położienije Rossii 1999, Goskomstat R.F., Moskwa

Na przemysł paliwowo-energetyczny przypada obecnie około trzecia część całej wartości produkcji przemysłowej (tab. 1.), natomiast udział przemysłu maszynowego i metalowego maleje. Ostatnio. wzrósł nieco udział wartości produkcji przemysłu spożywczego.

Współczesną Rosję określa się jako postsocjalistyczny kraj okresu przejściowego. Jeszcze w latach 1991-94 Rosja była w pierwszej dziesiątce krajów w wielkości produktu krajowego brutto (ponad 609 mld USD). W ciągu następnych sześciu lat zmalał o połowę (Radionowa I. A., 2000). Głęboki kryzys i związany z nim spadek produkcji w 1990 r. spowodował, że w produkcie krajowym brutto według parytetu siły nabywczej na 1 mieszkańca, Rosja znalazła się w czwartej dziesiątce na świecie, ustępując m. in. Polsce, Argentynie, Chile, Meksykowi, Urugwajowi i wielu innym krajom. Zmalał popyt na rynku krajowym na produkty przemysłu rosyjskiego. Wzrost produkcji przemysłu przetwórczego jest więc uzależniony także od wzrostu dochodów ludności Rosji. Najwięcej ucierpiał przemysł zbrojeniowy, maszynowy, chemiczny, a produkcja przemysłu lekkiego zmniejszyła się aż czterokrotnie. Niemały wpływ na tą sytuację miał wzrost importu. Dynamika produkcji przemysłowej zarówno ogółem, jak i w przeliczeniu na 1 mieszkańca - przyjmując 1990 rok za 100, obniżyła się w 1998 r. do 45 punktów, a w 1999 r. do 56 punktów.

Rok po wprowadzeniu reformy i po sierpniowym kryzysie, już w październiku 1998 po raz pierwszy zaznaczył się wzrost produkcji przemysłowej w całej Rosji, intensyfikując się w latach następnych. Zwiększyła się też nieco liczba regionów w których zaznaczył się wzrost produkcji przemysłowej. Bardzo duże zróżnicowanie przestrzeni geograficznej pod względem warunków przyrodniczych, poziomu rozwoju społeczno gospodarczego i kulturowego sprawia, iż procesy przemian dokonują się z różnym natężeniem $w$ układach lokalnych i regionalnych (Zioło, 2000). Reformująca się ekonomika rynkowa, a w niej transformacja struktur przemysłowych spowodowały znaczące zmiany, które wyraziły się m.in. powstaniem nowych gałęzi przemysłu. Nie mniej jednak dotychczasowe, ogromne zróżnicowanie poziomu rozwoju gospodarczego poszczególnych regionów Rosji, pozostało nadal. Prawie $40 \%$ wartości krajowej produkcji przemysłowej w 1999 r. pochodziło z 10 "regionów" - podmiotów administracyjnych (tab. 2.). Obecnie w Federacji Rosyjskiej jest 
89 podmiotów administracyjnych: 21 republik autonomicznych, 6 tzw. krajów (dużych powierzchniowo jednostek w obszarach, które w okresie tworzenia tych jednostek uznano za słabiej rozwinięte gospodarczo), 10 okręgów autonomicznych, 1 autonomiczny obwód, 49 obwodów (abłas't - podstawowa jednostka administracyjna pierwszego rzędu) i 2 miasta wydzielone („,federalnego znaczenia”) - Moskwa i Petersburg. Także dolna część rankingu pozostała bez zmian. Dziś, tak jak dawniej - na ostatnie najsłabiej rozwinięte 10 podmiotów administracyjnych przypada zaledwie $0,1 \%$ wartości przemysłowej produkcji kraju. Są to okręgi autonomiczne, $\mathrm{z}$ wyjątkiem tych gdzie wydobywa się ropę naftową i gaz ziemny, oraz republiki autonomiczne: Ałtaj, Tuwa i Kałmykia. Obecnie nie ma jednak środków na skuteczną realizację regionalnej polityki pomocy ekonomicznej dla tych słabo rozwiniętych terytoriów.

Tabela 2. Dziesięć pierwszych regionów - podmiotów administracyjnych w wielkości produkcji przemysłowej w 1999 r.

\begin{tabular}{|l|l|c|c|c|}
\hline L.p. & \multicolumn{1}{|c|}{ Regiony } & $\begin{array}{c}\text { Wielkość produkcji } \\
\text { przemysłowej } \\
\text { (w mld rubli) }\end{array}$ & $\begin{array}{c}\text { Udział w pro- } \\
\text { dukcji kraju } \\
\text { w 1998 r. (w \%) }\end{array}$ & $\begin{array}{c}\text { Udział w pro- } \\
\text { dukcji kraju } \\
\text { w 1999 r. (w \%) }\end{array}$ \\
\hline 1 & $\begin{array}{l}\text { Chanty-Mansyjski OA } \\
\text { (Reg. Zachodniosyberyjski) }\end{array}$ & 176,8 & 5,9 & 5,9 \\
\hline 2 & Moskwa & 175,0 & 5,7 & 5,8 \\
\hline 3 & $\begin{array}{l}\text { Kraj Krasnojarski } \\
\text { (Reg. Wschodniosyberyjski) }\end{array}$ & 124,5 & 4,1 & 4,2 \\
\hline 4 & $\begin{array}{l}\text { Obwód Swierdlowski } \\
\text { (Reg. Uralski) }\end{array}$ & 114,7 & 4,9 & 3,8 \\
\hline 5 & Obwód Samarski (Reg. Powolża) & 108,1 & 4,1 & 3,6 \\
\hline 6 & Petersburg & 104,7 & 3,1 & 3,5 \\
\hline 7 & Tatarstan R A (Reg. Powołża) & 100,5 & 3,5 & 3,4 \\
\hline 8 & $\begin{array}{l}\text { Obwód Czelabiński } \\
\text { (Reg. Uralski) }\end{array}$ & 91,1 & 3,6 & 3,1 \\
\hline 9 & $\begin{array}{l}\text { Baszkortostan R A } \\
\text { (Reg. Uralski) }\end{array}$ & 89,9 & 3,3 & 3,0 \\
\hline 10 & $\begin{array}{l}\text { Obwód moskiewski } \\
\text { (Reg. Centralny) }\end{array}$ & 81,7 & 2,7 & 2,7 \\
\hline & \multicolumn{1}{|c|}{ Ogółem } & 1167,0 & 41,2 & 39,0 \\
\hline
\end{tabular}

Źródła: „Ekspert” nr 39, 1999 r.; Socjalno-ekonomiczieskoje położienije Rossii 1999, Goskomstat R.F., Moskwa.

Federacja Rosyjska - to potężne, najważniejsze, suwerenne państwo w Wspólnocie Niepodległości Państw (WNP), nie tylko ze względu na powierzchnię $\left(17,1 \mathrm{mln} \mathrm{km}^{2}\right)$ i liczbę ludności $(145 \mathrm{mln})$. Dysponuje ogromnym potencjałem przyrodniczym, ekonomicznym i naukowym. Federacja Rosyjska odgrywała ogromną rolę w ekonomice byłego ZSRR. Także obecnie, jej rola w integracji WNP jest decydująca.

Sztuczna izolacja od światowego rynku i międzynarodowej konkurencji w ciągu wielu dziesięcioleci, doprowadziła do utraty zdolności konkurencyjnej produkcji przemysłu przetwórczego, a spadek produkcji w okresie pierestrojki i utrzymywanie ekonomicznych związków między krajami WNP tylko pogłębiły sytuację. 
Tym nie mniej Rosja zachowała dominująca rolę w ramach ekonomicznej przestrzeni WNP; przypada na nią około $80 \%$ produktu krajowego brutto i około $2 / 3$ produkcji przemysłowej WNP.

Od kilku lat (1995-2001) trwa intensywny proces koncentracji organizacyjnoprodukcyjnej i finansowej przedsiębiorstw przemysłowych, handlowych i energetycznych. Wśród wielu kompanii działających na terenie Rosji, 15. z nich ma zdecydowaną przewagę w zakresie obrotów i potencjału ekonomicznego. Są to: Elektroenergetyczne Sieci Rossii (RAO ES Rossii), Gasprom, kompania naftowa „LUKoil”, Auto-Waz, kompania naftowa "Surgutnieftigaz”, Norylskij Niekiel S.A., kompania naftowa „JUKOS”, kompania naftowa "Sibnieft”, Rostielkom, Ałmazy Rossii - Sacha, Baszkirska kompania paliw, Centralna kompania paliw, Siewierstal, Basznieftiechim, Sibirsko- Dalniewostocznaja nieftnaja kompania "Sidanko" („Ekspert” nr 36; 27.09 .1999 r.). Jak widać przemysł paliwowoenergetyczny odgrywa najważniejszą rolę w gospodarce rosyjskiej. Świadczy o tym także dalszy wzrost udziału nakładów inwestycyjnych na ten przemysł.

Te największe kompanie są uprzywilejowaną formą organizacji i koncentracji władzy gospodarczej i coraz silniej wpisują się w struktury władzy państwowej.

\section{Literatura}

Radionowa I. A., 2001. Ekonomiczieskaja gieografija i regionalnaja ekonomika, Moskowskij Liciej, Moskwa.

Rodionowa I A., Bunakowa T. M., 2000. Ekonomiczieskaja gieografija, Moskowskij Liciej, Moskwa.

Rossijskij statisticzieskij jeżiegodnik, z różnych lat. Gosudarstwiennyj Komitiet Rossijskoj Fiederacii po Statistikie, Moskwa.

Z. Szot (red.), 1996, Geografia gospodarcza Rosji, PWE, Warszawa.

Szot Z., 1998. Rosja [w:] Encyklopedia Geograficzna Świata, Europa, OPRESS, Kraków, T.V.

Szot Z., 2001. Przestrzenna organizacja gospodarki narodowej Federacji Rosyjskiej $w$ drugiej polowie lat 90. (studium przykładów). Prace Komisji Geografii Przemysłu PTG w Warszawie, Warszawa-Kraków-Rzeszów.

Szot. Z., 2001. Przestrzenna organizacja gospodarki narodowej Rosji w polowie lat 90. Sprawozdania z posiedzeń Komisji Naukowych PAN Oddz. w Krakowie, „SECESJA”, Kraków, T. XLIII/2,

Zioło Z., 2000. Problemy integracji międzynarodowej przemystu w procesie zmian systemu gospodarowania [w:] Problemy transformacji struktur przemysłowych w procesie przechodzenia do gospodarki rynkowej, Prace Komisji Geografii Przemysłu PTG w Warszawie, Warszawa-Kraków.

Zioło Z., 2001. Struktura branżowa $i$ koncentracja przestrzenna wiodacych światowych firm przemysłowych. Prace Komisji Geografii Przemysłu PTG w Warszawie, Warszawa-Kraków-Rzeszów.

Zioło Z., 2001. Problemy integracji międzynarodowej przemystu w relacji centrum - układ peryferyjny. Sprawozdania z posiedzen Komisji Naukowych PAN Oddz. w Krakowie, "SECESJA", Kraków, T. XLIII. 